\title{
Oceanographic changes and exploitation drive the spatio-temporal dynamics of Atlantic bluefin tuna (Thunnus thynnus)
}

\author{
Jean-Marc Fromentin ${ }^{1,}$, , Gabriel Reygondeau ${ }^{2}$, Sylvain Bonhommeau ${ }^{1}$, Gregory Beaugrand ${ }^{3}$ \\ ${ }^{1}$ Ifremer (Institut français de recherche pour l'exploitation de la mer), UMR 212 EME, Sète Cedex, France \\ 2 IRD (Institut de recherche pour le développement), UMR 212 EME, Sète Cedex, France \\ ${ }^{3}$ CNRS (Centre national de recherche scientifique), UMR 8187 LOG, Wimereux, France \\ *: Corresponding author : Jean-Marc Fromentin, email address : jean.marc.fromentin@ifremer.fr
}

\begin{abstract}
:
Atlantic bluefin tuna (ABFT) has always displayed spectacular changes in its spatial distribution, but the underlying mechanism of such variations still remains obscure. This study focuses on this challenging issue by scrutinizing the intriguing 'Brazilian episode' during which a large quantity of ABFT (a temperate species) was caught during the 1960s in the equatorial Atlantic. To investigate this event, we applied a niche model to an extensive data set of catch and environmental variables from 1960 to 2009. ABFT exhibited a remarkably large ecological niche, which matches well with our current knowledge of ABFT. Our results also depicted a high probability of ABFT occurrence in the South Atlantic and, more interestingly, favorable environmental conditions in the western equatorial Atlantic during the 1960s, but not later. ABFT could thus have migrated from their northern spawning grounds to the South Atlantic during the 1960s through the western equatorial Atlantic, playing the role of an 'ecological bridge'. We argue that the rarity of ABFT in the southern Atlantic during the last four decades would result from the interaction of several processes, particularly oceanographic conditions, migratory behavior, density-dependence, exploitation levels and population structure. Examination of the catch data further indicated that the fish caught in the equatorial Atlantic were from the western stock and we concluded that the lack of rebuilding of this stock could result from a regime shift due to the combination of oceanographic changes in the equatorial Atlantic and overfishing in the North Atlantic in the 1960s and 1970s.
\end{abstract}

Keywords: ecological niche model ; longline fisheries ; migration ; synergistic effects ; Thunnus thynnus; time series 


\section{Introduction}

Mediterranean fishermen have exploited Atlantic bluefin tuna (ABFT, Thunnus thynnus) since antiquity and used hundreds of fishing sites to profit from the seasonal migration along the coast toward their spawning sites (Ravier and Fromentin, 2001). These fisheries supplied a significant amount of the protein requirement to the human populations in Western Europe until the rise of cod and herring fisheries and remained important in Mediterranean countries until the mid- $20^{\text {th }}$ century (Doumenge, 1998). For the last two decades, ABFT has become an emblematic species of the world fisheries crisis (e.g., Worm et al., 2009) due to severe overfishing, high market value, recurrent illegal fishing and deficient governance at both the international and national levels (Fromentin and Ravier, 2005; WWF, 2008). This worrying situation distracts us from the long-lasting fascination that this species has had on philosophers and scientists because of its remarkable biological traits and intriguing migratory behavior (e.g., Aristote, IV B.C.; Sarmiento 1757; Heldt 1926; Sella 1929).

Throughout its thousand-year old exploitation, ABFT catch has never been stable, but has exhibited conspicuous long-term fluctuations resulting from environmentally-driven changes in ABFT migration patterns (Ravier and Fromentin, 2004). During the $20^{\text {th }}$ century, large Nordic and Japanese fisheries rapidly arose in unexpected fishing areas, i.e., the North and Norwegian Seas and the equatorial Atlantic, but suddenly disappeared after a few years or decades (Mather et al., 1995). A recent empirical study has related the enigmatic Nordic episode to changes in ABFT migration routes that may have been induced by the synergy of a rapid cooling of the North Atlantic in the early 1960 s with a decline in prey availability and local overfishing (Fromentin, 2009).

This brief historical perspective emphasizes frequent major changes in ABFT spatial distribution. This feature is rather uncommon among the other large pelagics fish (ICCAT, 2012) and appears to be environmentally driven, but the underlying ecological processes remain obscure. Our study focuses on this challenging and intriguing issue by scrutinizing one of the most striking changes in ABFT spatial distribution, the so-called "Brazilian episode", during which Japanese fishing boats caught large quantities of ABFT (a temperate species) in the equatorial Atlantic where they were targeting tropical tunas (mostly yellowfin and bigeye tuna, see ICCAT, 2012). The "Brazilian episode" occurred just after the collapse of the ABFT Nordic fisheries, but was much briefer. No clear link has been established between these two events; however, they could be related by similar underlying processes: modifications in oceanographic features of the Atlantic that may have affected ABFT migration routes and/or habitat.

To investigate the underlying processes of the "Brazilian episode", we applied an ecological niche model to characterize the abiotic niche of ABFT. Then, we compared the temporal variations in the probabilities of ABFT occurrence obtained from the niche model with the changes in the distributions of ABFT catch. As ABFT vertical behavior appears to be associated with the thermocline (Walli et al., 2009), we also studied long-term changes in the intensity and depth of the thermocline in the Atlantic and then investigated any potential relationship with changes in ABFT spatial distribution. We finally discussed our results and ABFT spatial and population dynamics in a broader context, paying special attention to migratory behavior, density-dependence, exploitation levels and population structure. 


\section{Material and Methods}

\subsection{Data}

The fit of an ecological niche model requires the most exhaustive dataset on ABFT occurrence from a spatial and temporal viewpoint. Therefore, we included all catch from the long line (LL) and purse seine (PS) fleets targeting this species. The LL fisheries displayed a wider spatial coverage of ABFT catch in the off-shore regions of the Atlantic and adjacent seas, while the PS fisheries were more concentrated in the coastal and continental shelf regions (ICCAT, 2012). Note that the "Brazilian episode" (i.e., ABFT catch in the equatorial Atlantic) was due to a single fleet: the Japanese longliners (JpLL), which was the only commercial fleet operating at a large scale at that time. ABFT catch and effort were spread over most of the Atlantic, i.e., from $122.5^{\circ} \mathrm{W}$ to $35.5^{\circ} \mathrm{E}$ and $63^{\circ} \mathrm{N}$ to $42.5^{\circ} \mathrm{S}$, with a spatial resolution of $5^{\circ}$ by $5^{\circ}$ for LL ( $n=6113$ observations) and $1^{\circ}$ by $1^{\circ}$ for $P S(n=4496$ observations) at a monthly resolution from 1960 to 2009. All ABFT catch and fishing effort were provided by the International Commission for the Conservation of Atlantic Tunas (ICCAT, http://www.iccat.es/).

The "Brazilian episode" is characterized by remarkably high catch of ABFT around the equator by the JpLL fleet during the 1960s (Fromentin and Powers, 2005; Mather et al., 1995). To define this episode more precisely, we summed all the catches of the JpLL fleet occurring solely in the tropical belt (i.e., between $20^{\circ} \mathrm{S}$ and $20^{\circ} \mathrm{N}$ ). The resulting time series showed that the onset of this event occurred in 1960-1961 (catches $340 \mathrm{t}$ ), while the highest catch of ABFT (from 1,200 $t$ to $8,300 \mathrm{t}$ ) occurred in the following four years (i.e., from 1962 to 1965). The "Brazilian episode" ended in 1966-1967 (catch $110 \mathrm{t}$ ). Since 1968, the JpLL catch of ABFT in this area have always been $<16 \mathrm{t}$ (and most often $<1 \mathrm{t}$, Supplementary Figure S1). Note that the Japanese fishery arose in 1956 in the Atlantic and that ABFT catch remained low during the late 1950s in the tropical belt (i.e., $0 \mathrm{t}$ in 1956, about $30 \mathrm{t}$ in 1957 and 1958, and increasing up to $200 \mathrm{t}$ in 1959, Figure S1). The "Brazilian episode" thus lasted eight years (from 1960 to 1967) and peaked over four years (from 1962 to 1965$)$.

Following Reygondeau et al. (2012), we selected three comprehensive environmental factors: (i) sea surface temperature (SST), (ii) bathymetry (i.e., depth of the sea floor) and (iii) sea surface salinity (SSS) to compute the ABFT ecological niche. Temperature is an essential factor affecting ABFT spatial distribution because of its influence on several key biological processes, such as reproduction, larval survival, growth (Brill et al., 2001; Teo et al., 2007), behavior at small-scales (Royer et al., 2004) and at large-scales (Druon et al., 2011). ABFT is a pelagic species that is mostly distributed in areas $>200 \mathrm{~m}$, but that can also be found on the continental shelf during reproduction or feeding (Block et al., 2001, Lutcavage et al., 2000). ABFT primarily reside in surface waters, but both juvenile and adult ABFT frequently dive to depths of $500 \mathrm{~m}$ to $1000 \mathrm{~m}$ (Block et al., 2001). Salinity affects most fish species through the process of osmoregulation (Bœuf and Payan, 2001) and may further influence the large-scale spatial distribution of tuna species (Reygondeau et al., 2012).

Monthly mean SST was extracted from the International Comprehensive Data Set (iCOADS) at a spatial resolution of $1^{\circ}$ for the period 1960 to 2009 (http://icoads.noaa.gov/). All areas with no information were filled using the extended Reconstructed Sea Surface Temperature (ERSST), which is computed using the iCOADS and the Advanced Very High Resolution Radiometer data sets (AVHRR, Smith et al.,= 2008). Bathymetry was downloaded from the GEneral Bathymetric Chart of the Oceans (GEBCO) on a $1^{\circ}$ by $1^{\circ}$ grid (Smith and Sandwell, 1997). As no exhaustive and validated time series of SSS were available, the climatology of monthly SSS was downloaded from the World Ocean Database 2009 (WOA09) at a $1^{\circ}$ by $1^{\circ}$ grid (Antonov et al., 2010). Doing so, we took into account changes in the spatial variability of 
SSS, but not interannual variability. All environmental data that were extracted over $132.5^{\circ} \mathrm{W}$ to $45.5^{\circ} \mathrm{E}$ and $75^{\circ} \mathrm{N}$ to $55^{\circ} \mathrm{S}$. We could not integrate the ocean color (i.e., chlorophyll a concentration estimated from remote sensing data) into the ABFT ecological niche due to the lack of data during the 1960s (and 1970s), a period which was central for this study. Furthermore, we could not use a climatology of ocean color (as we did for SSS) because of highly variable seasonal, interannual and decadal patterns (Martinez et al., 2009).

Water column stability directly influences the abundance, the species richness and the movement of marine species in the epipelagic waters. Studies have shown that intensity and/or depth of the thermocline could regulate the blooming period of plankton species (Reygondeau and Beaugrand, 2011) and also affect the vertical distribution of marine top predators (e.g., Pelletier et al., 2012). In this study, 1,731,000 profiles of temperature have been gathered from World Ocean Database website (http://www.nodc.noaa.gov/OC5/ SELECT/dbsearch/dbsearch.html), covering the Atlantic basin from $55^{\circ} \mathrm{S}$ to $70.5^{\circ} \mathrm{N}$ and $132.5^{\circ} \mathrm{W}$ to $45.5^{\circ} \mathrm{E}$ during the $1960-2009$ period. The intensity and depth of the thermocline was calculated using a procedure that identifies the depth and the intensity of the maximal gradient of each temperature profile (Reygondeau and Beaugrand, 2011). The monthly, yearly and decadal patterns were then inferred, using the NOAA procedure (Antonov et al., 2010). As for the ocean color, we could not integrate the intensity and/or depth of the thermocline into the ABFT ecological niche as there were too many missing values during the 1960 s and 1970s. Therefore, we only considered the average conditions for each month, year and geographical cells on a $2^{\circ}$ by $2^{\circ}$ grid for the 1960 to 2009 period to perform a simple correlation analysis with the other variables of interest.

\subsection{Statistical analyses}

Catch $>0.2 \mathrm{t}$ was considered as a presence of ABFT $(n=8822)$. The threshold of $0.2 \mathrm{t}$ was empirically chosen to circumvent any potential misidentification of the species (especially with the southern bluefin tuna, Thunnus maccoyii). For each geographical cell (pixel) that included an ABFT catch $>0.2 \mathrm{t}$, the corresponding values of SST, bathymetry and SSS of the given month and year were retrieved, so that we finally obtained a reference matrix of $n=$ 8822 observations and $p=3$ variables. The ABFT environmental niche was then characterized using a non-parametric probabilistic procedure called the Non Parametric Probabilistic Environmental Niche model (NPPEN, Beaugrand et al., 2011).

The NPPEN model is based on the concept of the ecological niche of Hutchinson (Hutchinson, 1957). It can be summarized as a test that calculates the dissimilarity of a given sample set (here, any geographical cell) to a known set (here, all the geographical cells in which ABFT catch has been observed). The method uses a generalized distance of Mahalanobis (Mahalanobis, 1936), which, instead of a classical Euclidian distance, presents a double advantage: (i) it enables the correlation between variables to be taken into account and (ii) it is independent of the scales of the descriptors. The probability of each grid point to belong to the reference matrix is then calculated by using a simplified version of the Multiple Response Permutation Procedure (MRPP) (Mielke et al., 1981). This probability is the number of times the simulated distance was found greater or equal than the observed average distance. If the probability is close to 1 , the environmental conditions of the tested point are at the centre of the ecological niche. A probability close to zero indicates that the environmental conditions of the point are outside of the ecological niche. In this study, NPPEN gives the probability of ABFT occurrence as a function of the three selected variables, which defines the ecological niche of the species. The probabilities of ABFT occurrence were estimated from the whole dataset, including all the catch and abiotic data from 1960 to 2009.

ABFT niche is thus solely computed in three dimensions, i.e., SST, SSS and bathymetry. The environmental envelope calculated by the model (Figure S2) does not vary in time 
(month and year) or space (longitude and latitude), as it represents the fundamental niche of the species. Nonetheless, NPPEN enables the probability of ABFT occurrence to be mapped according to the corresponding environmental conditions in each geographical cell of the studied area at a given time. Indeed, the ecological niche of ABFT calculated by NPPEN is an environmental envelope that relates the probability of ABFT occurrence to the values of the environmental variables. Therefore, the vector of SST, SSS and bathymetry in a given geographical cell can directly be translated into a given probability of ABFT occurrence in that cell, which leads to a map of ABFT occurrence. This mapping can be done over a given period of time by simply averaging the environmental conditions in each geographical cell over the months/years of that period. In the present study, we considered the whole period (1960-2009), the "Brazilian episode" (1960-1967, see above) and each decade between 1960 to 2009 . To do so, the time series of monthly SST were averaged in each geographical cell for each period of interest on a grid of $1^{\circ}$ by $1^{\circ}$. The annual climatology of SSS in each geographical cell was calculated by averaging the monthly climatology of SSS and was applied to each period of interest. Bathymetry in each geographical cell was assumed constant during the whole period studied.

\section{Results}

The ABFT abiotic niche (calculated from 1960 to 2009) is unusually large for a bony fish, as ABFT may sustain a range of temperature from $0^{\circ} \mathrm{C}$ to $30^{\circ} \mathrm{C}$, salinity from $31 \%$ to $39 \%$ and bathymetry from $0 \mathrm{~m}$ to $6000 \mathrm{~m}$ (Supplementary Figure S2). Mapping ABFT occurrence over the whole period (1960 to 2009) shows high probabilities in the North Atlantic and adjacent seas, especially offshore the northwestern African and southwestern European coasts, the central North Atlantic, the northeastern American coast, the western Mediterranean Sea and the Gulf of Mexico (Figure 1a). This result confirms numerous past studies based on catch information, but more interesting is the occurrence of high probabilities also in the South Atlantic at around $30^{\circ} \mathrm{S}$ and along the southwestern African coast.

To investigate the ABFT ecological niche during the "Brazilian episode" (i.e., from 1960 to 1967), we computed the map of the probability anomalies, calculated as the map of ABFT occurrence during the 1960 to 1967 minus the median probabilities calculated in each pixel from 1960 to 2009. During the "Brazilian episode", the ABFT ecological niche was rather similar as the one calculated from 1960 to 2009, except in the western equatorial Atlantic (and, secondarily, along the US Atlantic coasts), which displayed much higher probabilities (Figure 1b). The 1960s were the only decade over the last 50 years that exhibited relatively high probability of ABFT occurrence around the Equator (Figure S3). Since the 1970s, the equatorial Atlantic has been characterized by a band of low probabilities, which tend to widen with time and has reached the lowest levels of probability during the last decade (20002009). Also of interest are the higher probabilities of ABFT occurrence above $45^{\circ} \mathrm{N}$ during this last decade (Figure 1c).

We then superimposed the ABFT JpLL catch on the map of the probability anomalies of ABFT occurrence from 1960 to 2009 (summed over all the longitudes between $20^{\circ} \mathrm{E}$ and $90^{\circ} \mathrm{W}$, Figure $2 \mathrm{a}$ ). There has been a remarkable change in the spatial distribution of JpLL catch through time, with a clear shift from the equatorial Atlantic during the 1960s to the central North Atlantic (at around $30^{\circ} \mathrm{N}$ to $40^{\circ} \mathrm{N}$ ) during the 1970 s to 1980 s and to finally the northern North Atlantic (at around $50^{\circ} \mathrm{N}$ to $60^{\circ} \mathrm{N}$ ) since the mid-1990s. These changes in the spatial distribution of JpLL catch matched well the probabilities of ABFT occurrence (Figure 2a). Note that the absence of JpLL ABFT catch in the equatorial Atlantic during the last four decades was not due to a spatial shift of the JpLL fisheries. On the contrary, these fisheries have reinforced their effort in the tropical belt since 1970, where they continued to target and catch tropical tuna (Figure $2 \mathrm{~b}$ ). Furthermore, while the JpLL effort spread over the whole 
equatorial Atlantic during the 1960 s (i.e., from $20^{\circ} \mathrm{E}$ to $90^{\circ} \mathrm{W}$, see Figure S4), ABFT catch mostly occurred in the western part during the "Brazilian episode", where the probabilities of the ABFT ecological niche were much higher (Figure 1b).

The strongest anomalies were detected in the equatorial Atlantic during the 1960s and in the northern North Atlantic since the mid-1990s, indicating a northern shift of the probability of ABFT occurrence over the last five decades (Figure 2a). However, the northern location of JpLL ABFT catch was also due to the northern expansion of the JpLL fisheries since the mid1990s (Figure 2b).

Changes in the spatial distribution of JpLL catch have thus clearly coincided with the changes in the probabilities of ABFT occurrence. To investigate the statistical significance of this potential relationship, we computed the correlation between JpLL ABFT catch in the equatorial Atlantic (log-transformed to stabilize the variance) and the anomaly of the probability of the ABFT ecological niche. The Spearman correlation coefficient is positive and significant, even after the adjustment of the degrees of freedom to account for autocorrelation ( $r s=0.67$ and $p<0.05$, Figure $3 a, b$ ). This result indicates a log-linear relationship between both variables and tends to confirm that the "Brazilian episode" could be related to spatio-temporal variations in the ABFT ecological niche. There is also a statistically significant match $(p<0.05)$ between the anomalies of the depth and intensity of the thermocline and the JpLL catch in the equatorial Atlantic (Figure 3c, d). Note that the Spearman correlations between the four time series of Figure 3 are all significant at the $5 \%$ level, but those between the anomalies of probability of ABFT occurrence and the anomalies of the intensity or depth of thermocline are lower than this between the two thermocline variables (i.e., rs $=0.38,-0.39$ and -0.68 , respectively) .

\section{Discussion}

The application of a NPPEN model to a spatially- and temporally-extensive data set of ABFT catch allows us to uncover the remarkably large ecological niche of this species. ABFT can sustain a wide range of SSS (restricted to marine waters), depths (from coastal to off-shore oceanic regions) and SST (from tropical to subpolar seas). This high tolerance of ABFT to SST is probably related to its endothermic abilities to maintain muscle, eye, brain and visceral temperatures at relatively constant temperatures. This property is common to tuna species and some sharks and is highly developed in ABFT (Graham and Dickson, 2001). Nonetheless, the ABFT niche remains partly incomplete due to: (i) the lack of availability of other key environmental variables for the 1960s and 1970s, especially chlorophyll, (ii) the absence of spatio-temporal data of ABFT forage species over the Atlantic and (iii) the limited number of ABFT observations in coastal areas (such as the Gulf of St Lawrence), whose specific environmental characteristics cannot therefore be retrieved by the model. Furthermore, some regulations, such as the prohibition by ICCAT of a directed fishery on ABFT in the Gulf of Mexico since the early 1980s, or the late development of industrial fisheries in the eastern Mediterranean, led to underestimations of the probabilities of ABFT occurrence in those areas.

Despite those limitations, the mapping of the ABFT ecological niche matches well with our current knowledge of ABFT spatial distribution and oceanic habitat utilization that have been deduced from fisheries information (Fromentin and Powers, 2005; Mather et al., 1995) or intensive electronic tagging programs (Walli et al., 2009). The areas of highest probabilities of the ABFT ecological niche were offshore the northwestern African and southwestern European coasts, along the Northeast American coast and over the central North Atlantic, western Mediterranean Sea and Gulf of Mexico. The map of probability of ABFT occurrence thus reflects the map of the distribution of $A B F T$, but these two maps can differ in some 
points. For instance, the model can predict a rather high probability of occurrence in an area where ABFT has not been observed or caught, simply because the environmental conditions in that given area are, in general, favorable to ABFT.

All these areas are in the North Atlantic, which explains why ABFT has long been seen as a North Atlantic species. The present study also displays high probability of ABFT occurrence in central South Atlantic at around $30^{\circ} \mathrm{S}$ and along the southwestern African coast. This result is in agreement with a few old records mentioning ABFT catch in the South Atlantic (ICCAT, 2012). Nonetheless, the occurrence of ABFT in the South Atlantic has always been rare, except during the "Brazilian episode". Furthermore, no ABFT spawning sites have ever been documented in the southern hemisphere, which might explain the rarity of the species below the equator. The central South Atlantic might thus reflect the probability of occurrence of other close tuna species, such as the southern bluefin tuna or albacore tuna (Thunnus alalunga), which could display similar ecological niches. This hypothesis, however, does not explain why ABFT appeared in the equatorial and southern Atlantic during the 1960s and more rarely since then. Worm and Tittensor (2011) proposed that the disappearance of ABFT from the southern hemisphere (and so, the ABFT spatial range contraction), was due to exploitation, but the authors did not investigate the potential underlying mechanisms. We argue below that this range contraction would not only result from exploitation, but from the interaction among several factors or processes, particularly oceanographic conditions, migratory behavior, density-dependence, exploitation levels and population structure.

Our study shows favorable environmental conditions for ABFT in the equatorial Atlantic at the time of the "Brazilian episode", but not later. ABFT could have thus migrated from their northern spawning grounds to the South Atlantic during the 1960s through the western equatorial Atlantic, playing the role of an "ecological bridge", i.e., a large-scale oceanographic structure between the central North and the central South Atlantic. However, this bridge appears to have broken down in the late 1960s, which could make ABFT migration to the South Atlantic more difficult to achieve. This hypothesis is illustrated by the superimposition of seasonal JpLL ABFT catch on the map of probability of ABFT occurrence during the 1960s (Figure S5). This may depict a migration from the equatorial Atlantic to the western spawning ground of the Gulf of Mexico during the first semester and to a reverse north-south migration during the second part of the year.Consequently, the southeastern Atlantic feeding grounds (offshore of South Africa, Namibia and Angola) may well have been shared by both ABFT and southern bluefin tuna during the 1960 s.

The seasonal pattern of JpLL ABFT catch during the 1960s also indicates a connection between the equatorial Atlantic and the Gulf of Mexico spawning ground, but not with the Mediterranean spawning ground (although JpLL also operated in the Northeast Atlantic during that period, Figures S4 and S5). As ABFT presents high rates of natal homing (Rooker et al., 2008), JpLL would have solely exploited the ABFT western stock while fishing in the equatorial Atlantic during the 1960s. If so, there would have been little or no connection between the "Brazilian episode" and the collapse the ABFT Nordic fisheries in the early 1960s, which mostly operated on the East Atlantic and Mediterranean stock (Fromentin, 2009). The lack of biological archives of fish caught in the equatorial Atlantic during the 1960s does not allow us to retrieve the natal origin of those fish and thus to draw any firm conclusion on this specific issue. Nonetheless, our analysis brings original and important findings about the ABFT spatial distribution and dynamics, especially the temporary pathway in the western equatorial Atlantic and the occurrence of favorable habitat in the eastern and western South Atlantic (on both sides of the tropical gyre). These new elements have been summarized in an updated map of ABFT spatial distribution (Figure 4).

Because ABFT displays a large ecological niche, it has potentially more abiotic opportunities (i.e., a larger ecological window) than other large pelagic fish. This may explain why the ABFT spatial distribution appears generally more variable than those of other pelagic fish 
(Fromentin and Fonteneau, 2001). It is also likely that the ABFT spatial distribution may expand northward (beyond $60^{\circ} \mathrm{N}$ ) in the near future (as it did from the 1930s to the 1950s, MacKenzie and Myers, 2007) because of the effects of global warming. Our study and evidence from new fisheries grounds in the most northern regions (e.g., the Gulf of St Lawrence) since the 2000s indicate that this northward expansion has probably begun during the last decade. But, the question remains as to how ABFT are able to find these new regions. The simplest explanation is random search. Interestingly, our study exhibits a statistically significant match between the anomalies of the depth and intensity of the thermocline and the JpLL catch in the equatorial Atlantic. We thus hypothesize that thermocline may play a key role in ABFT migratory behavior. This oceanographic feature may act as an "ecological corridor" (i.e., a meso-scale oceanographic structure) that may allow ABFT to efficiently explore its environment and find new regions. This hypothesis is coherent with two other recent findings which showed that: (i) ABFT vertical behavior was closely associated to the thermocline, possibly for feeding (Walli et al., 2009) and (ii) the foraging activity and efficiency of another marine predator (the little penguin) was related to the detection of the thermocline, which could represent temporary indicators of enhanced food availability (Pelletier et al., 2012).

As with many other pelagic fish species, ABFT exhibit complex life-cycle patterns, adopting different migratory behavior at different times due to environmental cues. This is not surprising, as changes in environmental conditions have been already proposed to explain changes in ABFT spatial distribution or migration (e.g., Ravier and Fromentin, 2004; Sibert et al., 2006; Teo et al., 2007). Nonetheless, density-dependent processes could also play a role and interact with environmental conditions to modify ABFT migratory behavior. Huse et al. (2002) showed that changes in wintering areas and migration patterns of the Norwegian spring herring were related to the numerical dominance of strong year-classes, each one establishing new wintering grounds and new migratory pathways. In other words and according to the Contingent Hypothesis (Secor, 1999), the sudden appearance of large cohorts can induce substantial changes in the spatial distribution of pelagic fish. ABFT western stock could have thus produced large cohorts during the 1940s and 1950s, which explored new feeding grounds and migrated to the South Atlantic because of favorable environmental conditions in the equatorial Atlantic. Note that the historical Nordic fisheries were mostly supported by large cohorts from the 1940s and early 1950s in the eastern ABFT stock (Fromentin, 2009). These new geographical spots could have subsequently been transmitted from year to year through spatial learning and entrainment of younger fish (Petitgas et al., 2010). The "Brazilian episode" may have ended because of the closure of the "equatorial bridge".

Finally, the strong decline in ABFT western stock abundance during the 1970s (ICCAT, 2011) may have resulted from the loss of these highly migratory contingents due to local/regional overfishing in the 1960s and early 1970s. Indeed, from the late 1960s to the mid-1970s, JpLL catch in the whole western Atlantic remained low (i.e., about 700 t. per year against 4000 t. per year over 1960 to 1967) and the ABFT catch in the western Atlantic was, at that time, mostly taken by US purse seiners targeting smaller fish $(<30 \mathrm{~kg})$, i.e., different year-classes. Thus, the highly migratory ABFT contingents may have been either fished out or have beenoutside of the JpLL spatial range. The second hypothesis is, however, very unlikely because (i) the JpLL spatial range remained similar in the late 1960s and early 1970s (and even slightly expanded) and (ii) JpLL operated in the western ABFT spawning ground during the spawning season at that time. Although the JpLL was at its onset in the 1960s, this fleet could have fished out these large cohorts in a few years: the total JpLL catch in the equatorial Atlantic and in the whole western Atlantic were, from 1960 to 1967, about 19,000 t. and 32,500 .t, respectively, i.e., about 130,000 and 220,000 individuals.

From a meta-population perspective (as hypothesized for ABFT, see Fromentin and Powers, 2005), the loss of those highly migratory contingents could have resulted not only in a simple 
removal, but could have also affected ABFT population connectivity and productivity (Kerr et al., 2010). The lack of recovery of the western stock, after three decades of low quota, has often be seen as a consequence of overfishing in the Mediterranean, which may have severely decreased the number of ABFT that make trans-Atlantic migrations (ICCAT, 2011). We propose that this lack of stock recovery may also originate from the vanishing of these western migratory contingents. Such disappearance could result from a loss of phenotypic diversity due to overfishing and/or the absence of the "equatorial bridge" that could have closed the ABFT pathway to the South Atlantic since the 1970s. Thus, the ABFT western stock could be less productive currently than it was during the 1950s and 1960s. In other words, the ABFT western stock could have experienced a regime shift due to the combination of oceanographic changes in the equatorial Atlantic and overfishing in the North Atlantic in the 1960 s to 1970 s.

\section{Acknowledgments}

We received financial support from the French Ministry of Research (funding to G.R). Thanks are due to Philippe Cury for his support, Pierre Lopez for his help for the figures, Claire Saraux and Anne-Elise Nieblas for their inputs of the final document.

\section{References}

Antonov, J.I., Seidov, D., Boyer, T.P., Locarnini, R.A., Mishonov, A.V., Garcia, H.E., Baranova, O.K., Zweng, M.M. and Johnson, D.R. (2010) World Ocean Atlas 2009. Washington, D.C., U.S. Government Printing Office. 184 pp.

Aristote (IV B.C.) Histoire des animaux. Chapitre 13. Les migrations des poissons. Paris: Gallimard folio essais, $585 \mathrm{pp}$.

Beaugrand, G., Lenoir, S., Ibañez, F. and Manté, C. (2011) A new model to assess the probability of occurrence of a species based on presence-only data. Mar. Ecol. Progr. Ser. 424: 175-190.

Block, B.A., Dewar, H., Blackwell, S.B., Williams, T.D., Prince, E.D., Farwell, C.J., Boustany, A., Teo, S.L.H., Seitz, A., Walli, A. and Fudge, D. (2001) Migratory Movements, Depth Preferences, and Thermal Biology of Atlantic Bluefin Tuna. Science 293: 1310-1314.

Bœuf, G. and Payan, P. (2001) How should salinity influence fish growth? Comparative Biochemistry and Physiology. Tox. Pharm. 130C: 411-423.

Brill, R.W., Lutcavage, M.E., Metzger, G., Bushnell, P.G., Arendt, M., Lucy, J., Watson, C. and Foley, D. (2001) Horizontal and vertical movements of juvenile bluefin tuna (Thunnus thynnus) in relation to oceanographic conditions of the western North Atlantic, determined with ultrasonic telemetry. Fish. Bull. $100: 155-167$.

Doumenge, F. (1998) L'histoire des pêches thonières. Collective Volume of Scientific Papers ICCAT $50: 753-803$

Druon, J.N., Fromentin, J.M., Aulanier, F. and Heikkonen, J. (2011) Potential feeding and spawning habitats of Atlantic bluefin tuna in the Mediterranean Sea. Mar. Ecol. Progr. Ser. 439: 223240.

Fromentin, J.-M. (2009) Lessons from the past: investigating historical data from bluefin tuna fisheries. Fish Fish. 10: 197-216.

Fromentin, J.-M. and Fonteneau, A. (2001) Fishing effects and life history traits: a case-study comparing tropical versus temperate tunas. Fish. Res. 53: 133-150.

Fromentin, J.-M. and Powers, J.E. (2005) Atlantic bluefin tuna: population dynamics, ecology, fisheries and management. Fish Fish. 6: 281-306.

Fromentin, J.-M. and Ravier, C. (2005) The East Atlantic and Mediterranean bluefin tuna stock: looking for sustainability in a context of large uncertainties and strong political pressures. Bull. Mar. Sci. 76: 353-362.

Graham, J.B. and Dickson, K.A. (2001) Anatomical and physiological specializations for endothermy. In: Tuna. Physiology, ecology, and evolution. B.A. Block and E.D. Stevens (eds) San Diego: Academic Press. pp. 121-165. 
Heldt, M.H. (1926) Thon rouge - Résumé de nos connaissance actuelle sur le thon rouge (Orcynnus thynnus L.), 1ère partie. Rapp. P.-v. Réun. Comm. int. Explor. Scient. Mer Médit. 1: 99-120.

Huse, G., Railsback, S. and Feronö, A. (2002) Modelling changes in migration pattern of herring: collective behaviour and numerical domination. J. Fish Biol. 60: 571-582.

Hutchinson, G.E. (1957). A treatise on limnology, vol. 1. Geography, Physics and Chemistry. NewYork: Wiley. 1015pp.

ICCAT (2011) Report of the 2010 Atlantic Bluefin Tuna Stock Assessment Session. Collective Volume of Scientific Papers ICCAT 66: 505-714.

ICCAT (2012) Statistical Bulletin. Madrid, International Commission for the Conservation of the Atlantic Tunas (ICCAT). $156 \mathrm{pp}$.

Kerr, L.A., Cadrin, S.X. and Secor, D.H. (2010) Simulation modelling as a tool for examining the consequences of spatial structure and connectivity on local and regional population dynamics. ICES J. Mar. Sci. 67: 1631-1639.

Lutcavage, M.E., Brill, R.W., Skomal, G.B., Chase, B.C., Goldstein, J.L. and Tutein, J. (2000) Tracking adult North Atlantic bluefin tuna (Thunnus thynnus) in the northwestern Atlantic using ultrasonic telemetry. Mar. Biol. 137: 347-358.

MacKenzie, B.R. and Myers, R.A. (2007) The development of the northern European fishery for north Atlantic bluefin tuna Thunnus thynnus during 1900-1950. Fish. Res. 87, 229-239.

Mahalanobis, P.C. (1936) On the generalised distance in statistics. Proc. Nat. Inst. Sci India, 2: 49-55.

Martinez, E., Antoine, D., D'Ortenzio, F. and Gentili, B. (2009) Climate-driven basin-scale decadal oscillations of oceanic phytoplankton. Science 326: 1253-1256.

Mather, F.J., Mason Jr, J.M. and Jones, A. (1995) Historical document: life history and fisheries of Atlantic bluefin tuna. Miami, NOAA Technical Memorandum NMFS-SEFSC-370. 165 pp.

Mielke, P.W., Berry, K.J. \& Brier, G.W. (1981) Application of multiresponse permutation procedures for examining seasonal changes in monthly mean sea-level pressure patterns. Monthly Weather Review 109: 120-126.

Pelletier, L., Kato, A., Chiaradia, A. and Ropert-Coudert, Y. (2012) Can Thermoclines Be a Cue to Prey Distribution for Marine Top Predators? A Case Study with Little Penguins. PLOS ONE 7: e31768.

Petitgas, P., Secor, D.H., McQuinn, I., Huse, G. and Lo, N. (2010) Stock collapses and their recovery: mechanisms that establish and maintain life-cycle closure in space and time ICES J. Mar. Sci. 67: 1841-1848.

Ravier, C. and Fromentin, J.-M. (2001) Long-term fluctuations in the Eastern Atlantic and Mediterranean bluefin tuna population. ICES J. Mar. Sci. 58: 1299-1317.

Ravier, C. and Fromentin, J.-M. (2004) Are the long-term fluctuations in Atlantic bluefin tuna (Thunnus thynnus) population related to environmental changes? Fish.Oceanogr. 13, 145-160.

Reygondeau, G. and Beaugrand, G. (2011) Water column stability and Calanus finmarchicus. J. Plankton Res. 33: 119-136.

Reygondeau, G., Maury, O., Beaugrand, G., Fromentin, J.M., Fonteneau, A. and Cury, P. (2012) Biogeography of tuna and billfish communities. J. Biogeogr. 39: 114-129.

Rooker, J.R., Secor, D.H., DeMetrio, G., Schloesser, R., Block, B.A. and Neilson, J.D. (2008) Natal Homing and Connectivity in Atlantic Bluefin Tuna Populations. Science 322, 742-744.

Royer, F., Fromentin, J.-M. and Gaspar, P. (2004) The association between bluefin tuna schools and oceanic features in the Western Mediterranean Sea. Mar. Ecol. Progr. Ser. 269 : 249-263.

Sarmiento, F.M. (1757) De los Atunes y sus Transmigraciones y Conjesturas sobre la decadencia de las Almadrabas y sobre los medios para Restituirlas. Facsimil Caixa de Pontevedra. Madrid.

Secor, D.H. (1999) Specifying divergent migrations in the concept of stock: the contingent hypothesis. Fish. Res. 43: 13-34.

Sella, M. (1929) Migrazioni e habitat del tonno (Thunnus thynnus, L.) studiati col metodo degli ami, con osservazioni su l'accrescimento, sul regime delle tonnare ecc. Memoria R. Comitato Talassografico Italiano 156: 511-542.

Sibert, J.R., Lutcavage, M.E., Nielsen, A., Brill, R.W. and Wilson, S.G. (2006) Interannual variation in large-scale movement of Atlantic bluefin tuna (Thunnus thynnus) determined from pop-up satellite archival tags. Can. J. Fish. Aquat. Sci. 63, 2154-2166.

Smith, T.M., Reynolds, R.W., Peterson, T.C., Lawrimore, J. (2008) Improvements to NOAA's Historical Merged Land-Ocean Surface Temperature Analysis (1880-2006). J. climate 21: 2283-2296.

Smith, W.H.F. and Sandwell, D.T. (1997) Global sea floor topography from satellite altimetry and ship depth soundings. Science 277: 1956-1962.

Teo, S.H., Boustany, A., Dewar, H., Stokesbury, M.J.W., Weng, K.C., Beemer, S., Seitz, A.C., Farwell, C.J., Prince, E.D. and Block, B.A. (2007) Annual migrations, diving behavior, and thermal 
biology of Atlantic bluefin tuna, Thunnus thynnus, on their Gulf of Mexico breeding grounds. Mar. Biol. 151: 1-18.

Walli, A., Teo, S.L.H., Boustany, A., Farwell, C.J., Williams, T., Dewar, H., Prince, E. and Block, B.A. (2009) Seasonal Movements, Aggregations and Diving Behavior of Atlantic Bluefin Tuna ( Thunnus thynnus) Revealed with Archival Tags. PLoS ONE 4: e6151.

Worm, B., Hilborn, R., Baum, J.K., Branch, T.A., Collie, J.S., Costello, C., Fogarty, M.J., Fulton, E.A., Hutchings, J.A., Jennings, S., Jensen, O.P., Lotze, H.K., Mace, P.M., McClanahan, T.R., Minto, C., Palumbi, S.R., Parma, A.M., Ricard, D., Rosenberg, A.A., Watson, R. and Zeller, D. (2009) Rebuilding Global Fisheries. Science, 325: 578-585.

Worm, B. and Tittensor, D.P. (2011) Range contraction in large pelagic predators. Proc. Nat. Acad. Sci. 108: 11942-11947.

WWF (2008) Race for the last bluefin. Zurich, WWF Mediterranean. 126pp.

\section{Figure}

Figure 1: Maps of the probabilities of Atlantic Bluefin tuna (ABFT) occurrence deduced from the NPPEN niche model (see Methods): (a) for the entire period (1960 to 2009); (b) map of the anomalies of the probabilities of ABFT occurrence during the "Brazilian episode" (computed as the map of ABFT occurrence over 1960 to 1967 minus the median probabilities calculated in each pixel from 1960 to 2009); and (c) same as (b) for the period 2000 to 2009.

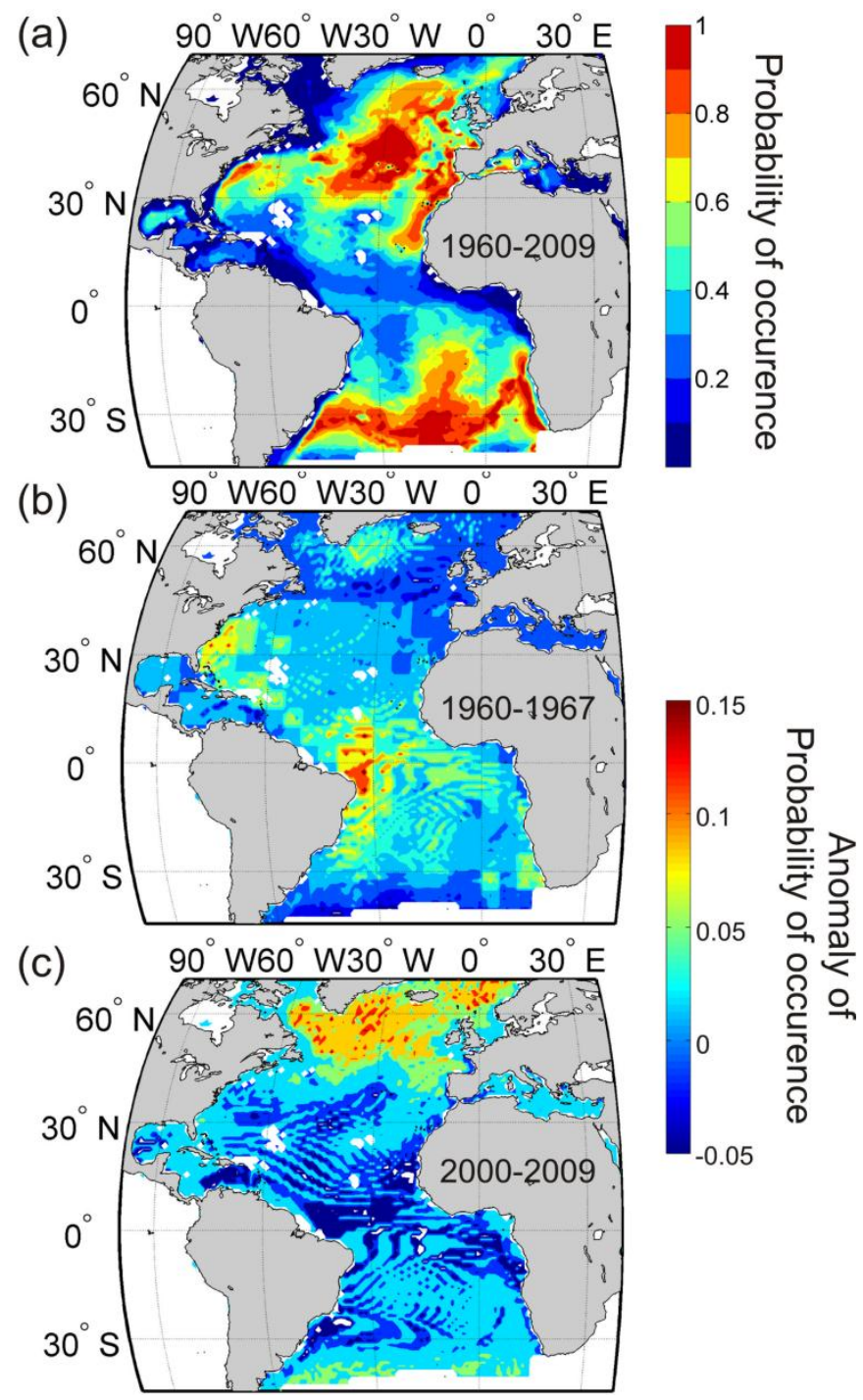


Figure 2: Maps of the probabilities of ABFT occurrence with fisheries information cumulated over all longitudes: (a) annual anomalies of the probabilities of ABFT occurrence (computed as the annual ABFT occurrence minus the median probabilities calculated in each pixel from 1960 to 2009) together with the catch of the Japanese longline fishing fleet (black circles) per year and per latitude; (b) effort of the Japanese longline fishing fleet per year and per latitude.

(a)
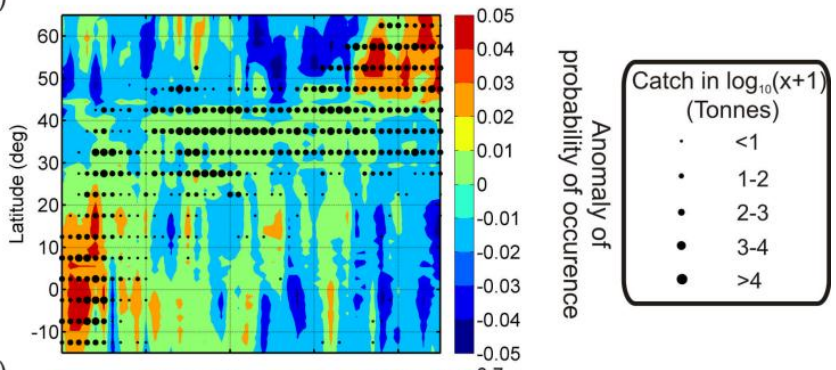

(b)

Figure 3: Plots of the time series (1960 to 2009, $n=50$ ) of: (a) cumulated ABFT catch (logtransformed) from the Japanese longline fishing fleet between $20^{\circ} \mathrm{S}$ and $20^{\circ} \mathrm{N}$ in the Atlantic; (b) anomalies of the probabilities of ABFT habitat ( $r s$ is the Spearman correlation coefficient between time series (a) and (b) and $p$ is the associated probability computed after the adjustment of the degrees of freedom to account for autocorrelation); (c) anomalies of the depth of the thermocline in the equatorial Atlantic ( $r s$ is the Spearman correlation coefficient between time series (a) and (c)); and (d) anomalies of the intensity of the thermocline in the equatorial Atlantic ( $r$ is the Spearman correlation coefficient between time series (a) and (d)). The vertical light grey box corresponds to the whole period of the "Brazilian episode", while the vertical dark grey box corresponds to the core of the "Brazilian episode".

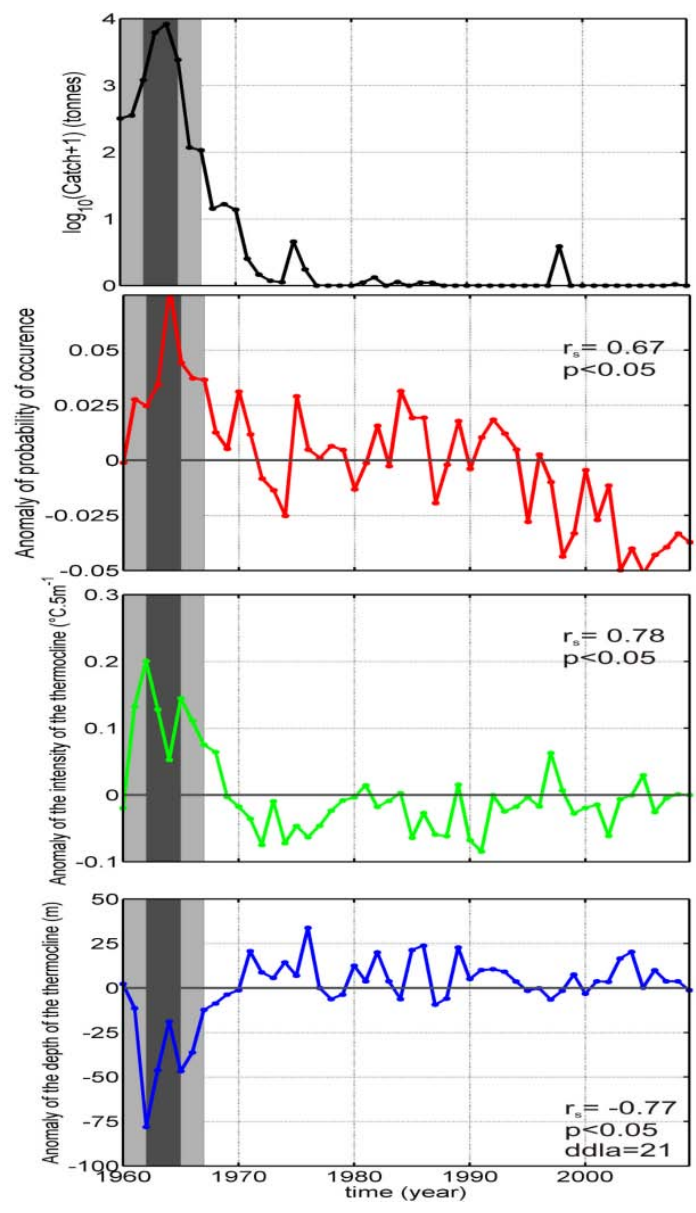


Figure 4: Spatial distribution of Atlantic bluefin tuna and main migration routes deduced from past literature and present work.

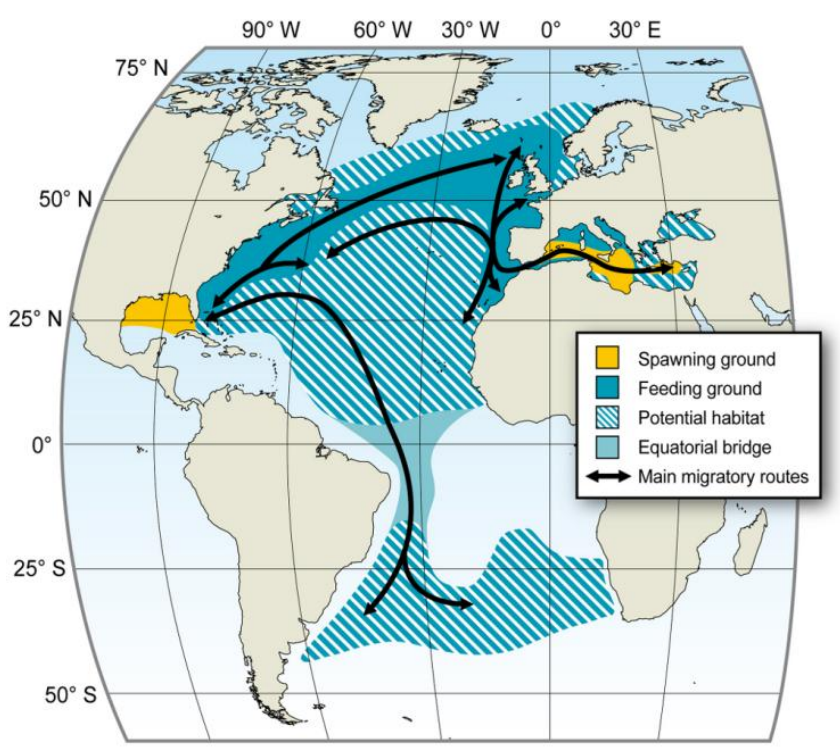

\section{Supplementary Figures}

Figure S1: Cumulated catch (raw data) of the Japanese longline fishing fleet in the equatorial Atlantic from 1957 to 2009. The vertical light grey box corresponds to the whole period of the "Brazilian episode", while the vertical dark grey box corresponds to the core of the "Brazilian episode".

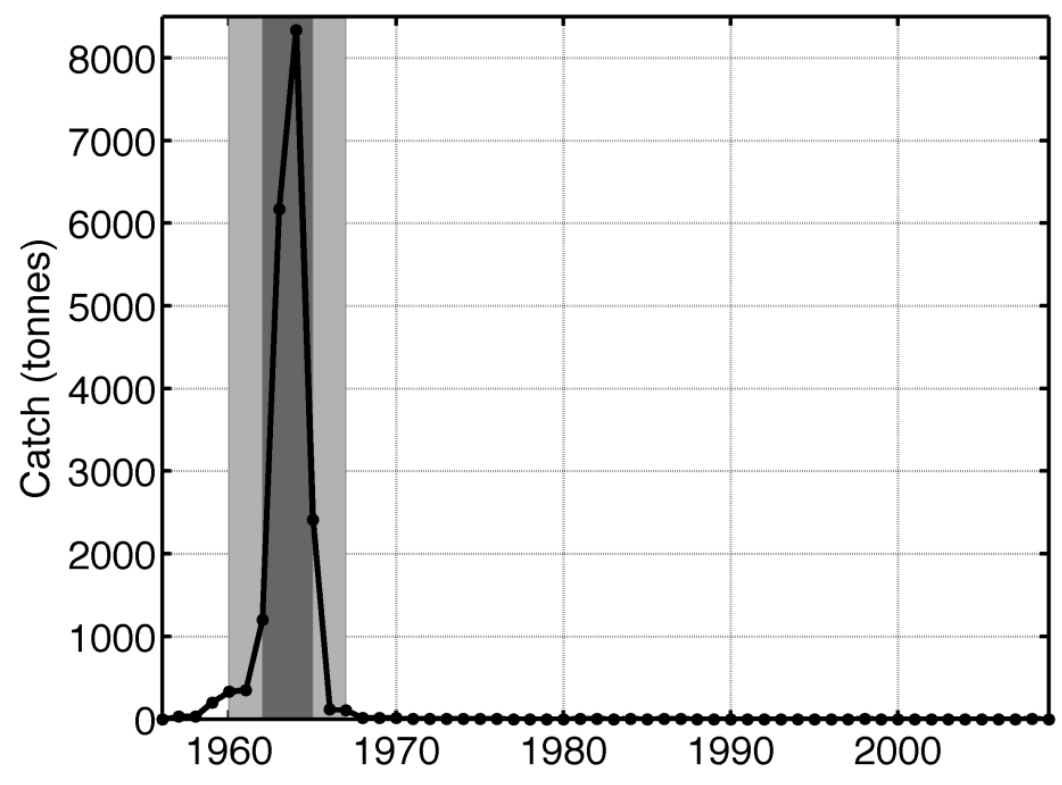


Figure S2: Probability of ABFT occurrence (the realized ABFT niche) as a function of the three selected variables: (a) sea surface temperature and bathymetry, (b) salinity and bathymetry and (c) sea surface temperature and salinity.
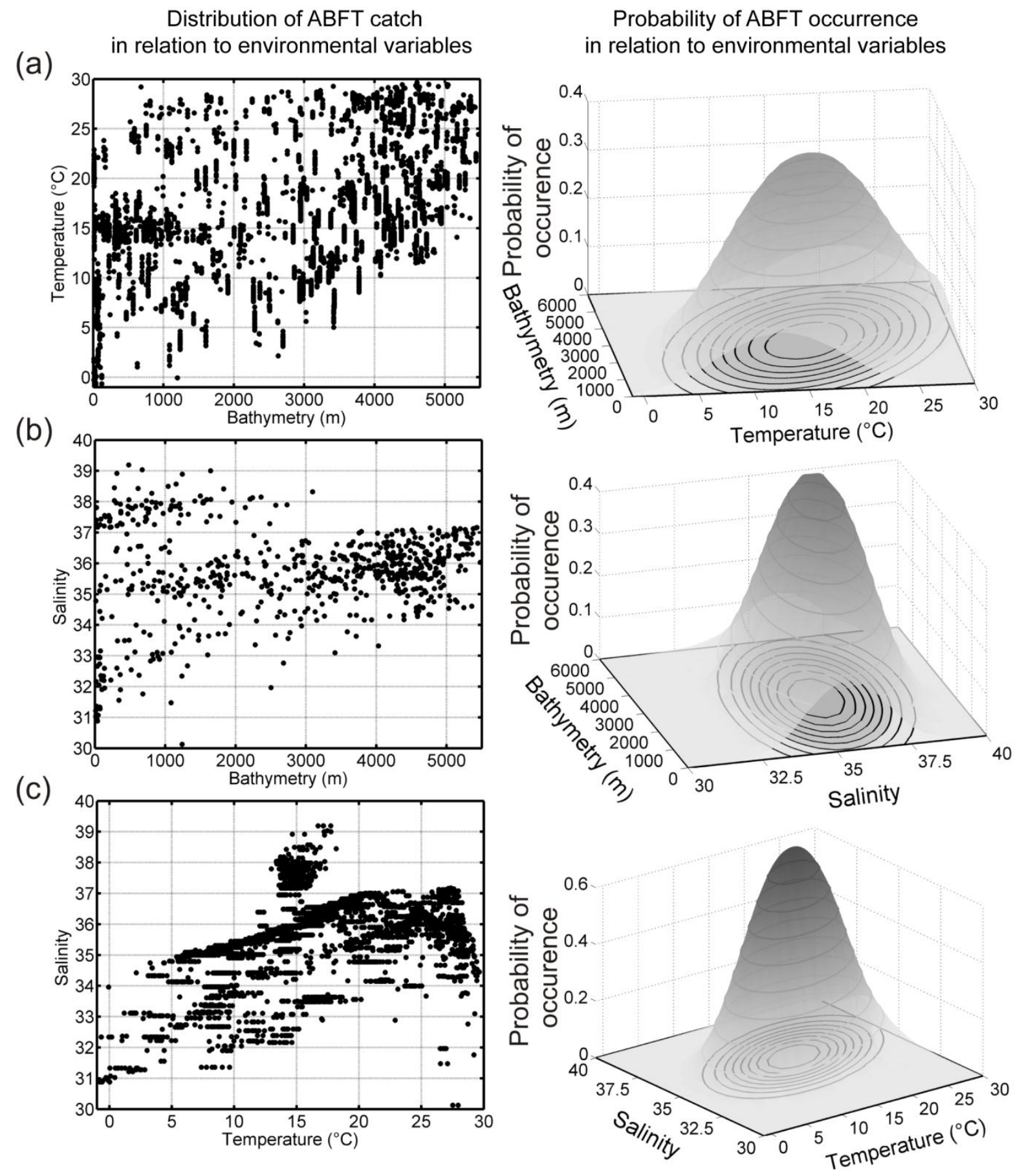
Figure S3: Decadal maps of the probabilities of ABFT occurrence during: (a) the "Brazilian episode", (b) the 1970s, (c) the 1980s, (d) the 1990s and (f) the 2000s.

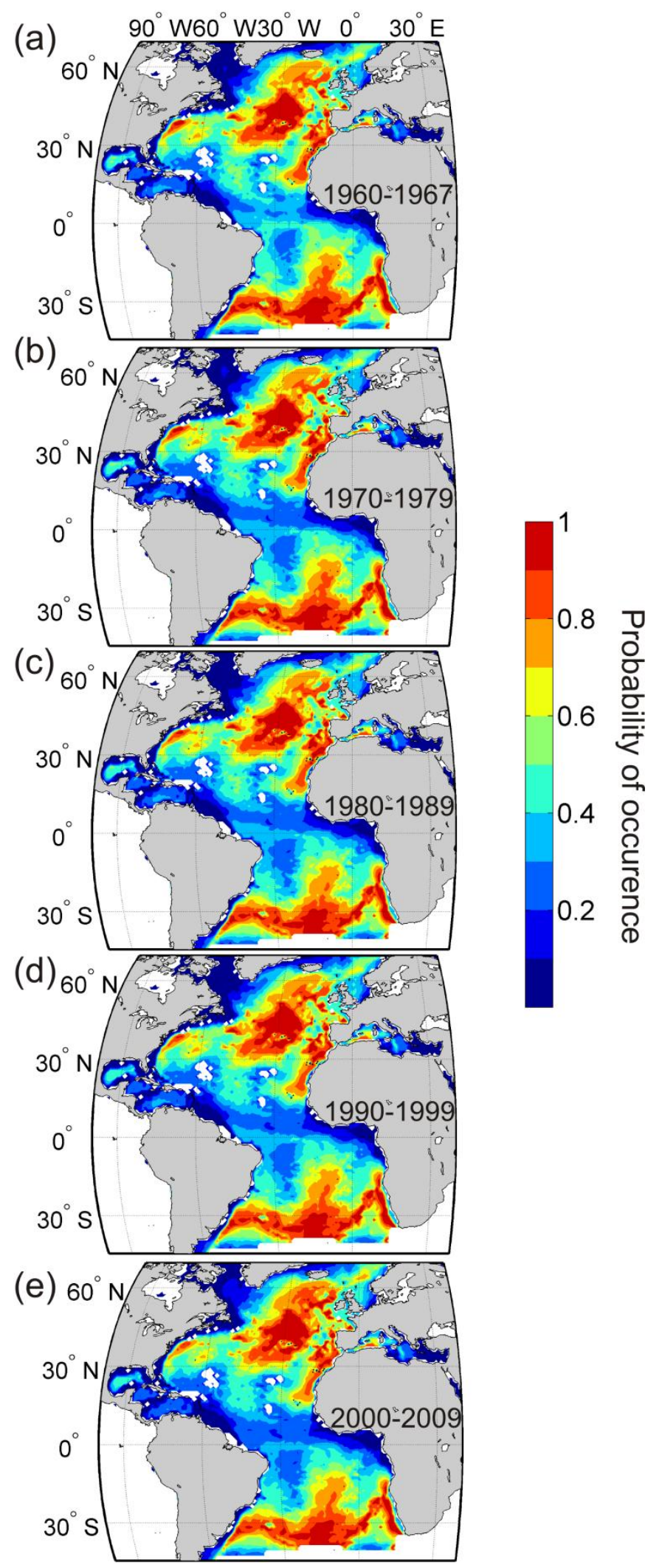


Figure S4: Maps of the probabilities of ABFT occurrence with fisheries information cumulated over all latitudes: (a) annual anomalies of the probabilities of ABFT occurrence (computed as the annual ABFT occurrence minus the median probabilities calculated for each pixel from 1960 to 2009) together with the cumulated catch of the Japanese longline fishing fleet (black circles) per year and per longitude; (b) cumulated effort of the Japanese longline fishing fleet per year and per longitude.
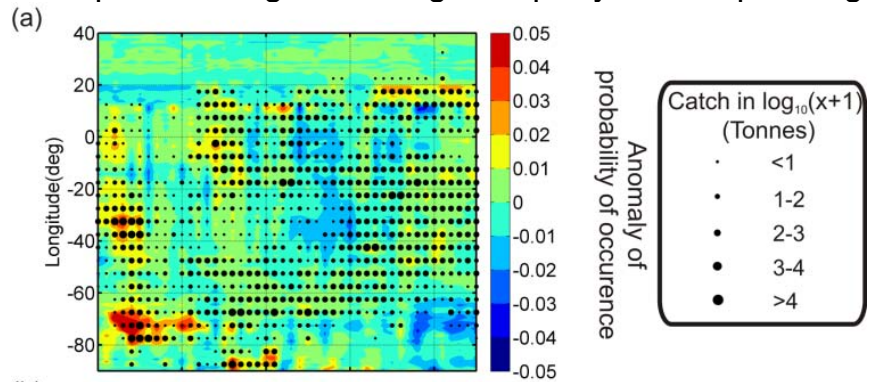

(b)
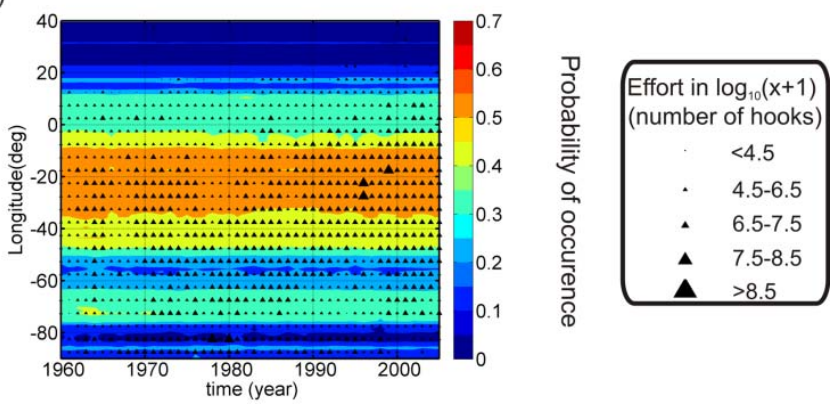

Figure S5: Seasonal maps of the probabilities of occurrence together with the corresponding cumulated catch of the Japanese longline fishing fleet (black circles) for 1960 to 1967 (left panel) and 1970 to 2009 (right panel).
